\title{
What Do We Know about Biofuels Today that Diesel and Ford Did Not?
}

\author{
Corina MARINESCU1 \\ Claudiu CICEA2
}

\begin{abstract}
Would have ever thought Rudolf Diesel and Henry Ford that a day will come when fuel will be extracted from algae? What would Diesel say when hearing about biodiesel or green diesel? Or would Ford say "I told you so" when discovering that ethanol became a reliable fuel? We would be proud to tell them how many efforts have been made and how many scientists and researchers dedicated their work to biofuels. The present paper makes an introduction into the biofuels' field and tries to answer the question raised in the title by providing a genuine configuration of biofuels generations and supporting evidence of their trends which will help both Ford and Diesel catch up with progress. By their nature, biofuels remain a large debated subject, a useful tool for tackling energy questions and a growing alternative to be explored in more depth.
\end{abstract}

KEYWORDS: bioenergy, biofuels, biodiesel, bioethanol.

JEL CLASSIFICATION: $Q 16$.

\section{INTRODUCTION}

Debating on a work of Blanchard (2000) who asked himself a similar question: "What do we know about macroeconomics that Fisher and Wicksell did not?" inspired us in relating biofuels with two references in our field of interest. The first one is Rudolf Diesel, the famous German inventor of diesel engine. His contribution to biofuel consists of the trial of running the engine with peanut oil. He was a visionary who believed in agricultural development of countries using vegetable oils. The second one is Henry Ford, who made his Model T vehicle to run on ethanol. He believed that America could rely on this type of fuel, if some day oil would not be available anymore. His predictive belief came true when the oil crisis began.

Modern biofuels impress not only by their natural advantages but also by running well inside and outside an engine. We are able to discuss today about three generations of biofuels, divided by their degree of novelty and by their capability of being green. According to Dahiya (2015), the first-generation biofuels is produced from oils, sugars, and starches found in food crops. The sources of the second-generation refer to nonfood crops (perennial grasses and woody materials) and nonfood portions of food crops, while the third-generation's main source is algae, followed by fast growing trees, also known as "energy crops".

Biofuels are considered a type of bioenergy, which is renewable energy derived from natural sources and are defined by Food and Agriculture Organization of the United Nations (2004) as "fuel(s) produced directly or indirectly from biomass". They are also seen as solid, liquid, and gas fuels (Dahiya, 2015).

\footnotetext{
${ }^{1}$ The Bucharest University of Economic Studies, Romania, corina.marinescu@ man.ase.ro

${ }^{2}$ The Bucharest University of Economic Studies, Romania, claudiu.cicea@man.ase.ro
} 
This paper makes an introduction into the biofuels' field, and tries to answer the question raised in the title "What Do We Know about Biofuels Today that Diesel and Ford Did Not?" in order to show advances within the field. Moreover, in the second part of the paper, with the aim to provide an overview for biofuels development in the last decades, the authors refer to several aspects regarding biofuels production and consumption, production costs and needed investments, the innovative capacity and the employment within the field.

\section{THREE GENERATIONS OF BIOFUELS}

The answer to our question is based on research evidence regarding different types of biofuels known today and how they run with Diesel's and Ford's engines. Biofuels differ one from another by feedstock used, costs, production process, energy density and greenhouse gases emissions. An interesting and comprehensive classification is the one dividing biofuels in three generations (Biofuel.org.uk, 2010; Naik et al. 2010).

We constructed Figure 1 which highlights an essential characteristic of modern biofuels from second and third generation: they are "greener" than previous ones, even if fewer, in a developing stage and less consumed. The colours within Figure 1 indicate that newer they are, greener they are. This special characteristic of modern biofuels refers to several facts. First, they do not need a large amount of feedstock from crop production, so they do not affect food supply. For instance cellulosic ethanol is extracted from agricultural waste while for obtaining ethanol, corn kernels are needed (Service, 2014). Second, they release fewer greenhouse gas emissions when burning or none in case of biohydrogen. Third, their production does not have adverse impact on soil, water or food supply.

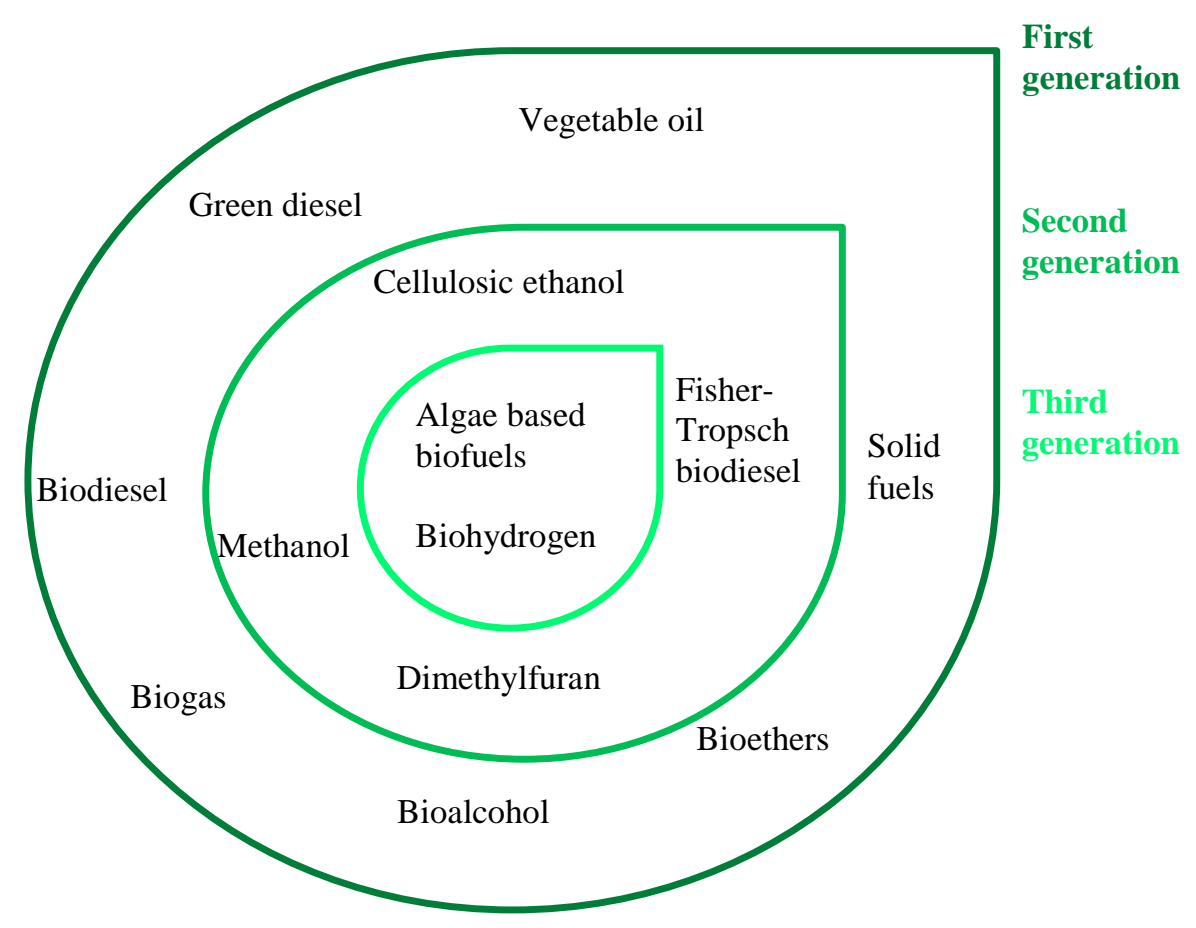

Figure. 1. Three Generations of Biofuels

Source: Authors after Biofuel.org.uk (2010)

Within the bioalcohol category are included ethanol, propanol, butanol, while the Vegetable oil category includes castors oil, fat, olive oil, sunflower oil. Solid biofuels comprise wood, dried plants, bagasse, manure and seeds (Biofuel.org.uk, 2010). In contrast to first generation 
of biofuels, which are based on sugar and starches from different crops, the second and third generations of biofuels get deeper in the plant matter composition. They look for cellulose, hemicellulose and lignin which can be converted in ethanol. These components were called "key global biomass resources" (Ragauskas et al., 2006) and scientists and researchers concentrated on discovering proper technologies that facilitate their conversion to biofuels. For instance, plant cells have a natural resistance to procedures needed for conversion, so effective measures to surpass this difficulty are needed (Himmel et al., 2007). Advanced studies on fungi and bacteria which are able to degrade biomass and reduce its recalcitrance are major challenges (Brunecky et al., 2013; Sardesai et al., 2013; Book et al., 2014; Yokoyama et al., 2014). They provide solutions to plant biomass deconstruction, contributing in this way to a lower cost of biofuel production. Indeed, most of biofuels are expensive to obtain. For instance, the third generation is as controversial as it can be. Even if algae based biofuels produce less greenhouse gas emissions, the production of fertilizers required for their cultivation is pollutant and exceeds the reductions provided by using them. So, while biofuel consumption is associated with reduced emissions, biofuel production incurs the so-called carbon debt (Searchinger et al., 2008; Fargione et al., 2008; Melillio et al., 2009). There is a diversity of algae with potential for biofuel production. A preferred classification is the one of microalgae (organisms of one cell) and macroalgae (organisms of multiple cells) or seaweeds. They are both of great interest for worldwide researchers' studies and engineering strategies (Brennan \& Owende, 2010; Wijffels \& Barbosa, 2010; Wargacki et al., 2012).

So, we have multiple choices for displacing petroleum fuels, but what kind of technical structures do we need? Systems which support the consumption of solid, liquid and gaseous biofuels were also developed or improved along time. The internal combustion engine of Rudolf Diesel is now designed to run with biodiesel blended with diesel. Other blends like ethanol with gasoline require several changes of the regular engine. Properties of biofuels (molecular weight, density, exergy, boiling point, carbon and sulfur content, lower heating value) are different from those of fossil fuels, affecting in a distinct way the engine's performance, materials, amount of deposits and emissions (Agarwal, 2007).

Long term effects on the engine's performance and durability were discovered for ethanoldiesel blends (Hansen, Zhang \& Lyne, 2005), Methyl tertiary butyl ether, methanol and ethanol in gasoline (Al-Farayedhi, Al-Dawood \& Gandhidasan, 2004), n-butanol and diesel (Şahin \& Aksu, 2015) and the examples could go on. These effects refer to improved characteristics of the engine, such as thermal efficiency, the brake power output and exhaust emission.

Important for the design of an engine combustor is understanding how biofuels "behave" in contact with solid surfaces (Rioboo, Marengo \& Tropea, 2002; Sen, Vaikuntanathan \& Sivakumar, 2014). For instance, thorough examinations of engines parts like cylinder, piston and injector were undertaken after using in parallel biodiesel blends and diesel (Agarwal, Bijwe \& Das, 2003). Wear measurements showed better reactions of vital parts for the biodiesel-fueled system.

So, it is clear that bio-origin fuels "behave" well inside the engine. We all know that they also act great outside, by being less pollutant, environment-friendly and biodegradable. Would Diesel and Ford understand why do we care about emissions? Our world is confronted with serious environmental problems and we would have to tell them about climate change (Karl \& Trenberth, 2003; Alley et al., 2003), ozone depletion (Ravishankara, Daniel \& Portmann, 2009), acid rain (Reis et al., 2012) and other environmental degradation effects which increase our society's vulnerability. We agree that technological readiness (Hoffert et al., 
2002) to handle climate problems delays, even though some claim that humanity has "the fundamental scientific, technical, and industrial know-how to solve the carbon and climate problem for the next half-century" (Pacala \& Socolow, 2004).

\section{TRACKING BIOFUELS FOR DIESEL AND FORD}

In order to provide an overview for biofuels development in the last decades, we will further refer to several aspects regarding the installed capacity, biofuels consumption, production costs or needed investments, the innovative capacity (translated here as filled patents) and the employment in the field. The International Renewable Energy Agency (IRENA) presents statistical data regarding all these aspects describing the situation for biofuels. We will further show and discuss some statistics for countries around the world and peers in the industry.

\subsection{Installed Capacity}

Within Table 1, one can found the values for installed capacity in MW for solid biofuels, liquid biofuels and biogas at a global level and for pioneers country in the field.

Table 1. Installed Capacity by Type of Biofuels

\begin{tabular}{|c|c|c|c|c|c|c|}
\hline $\begin{array}{l}\text { No } \\
\text { crt. }\end{array}$ & $\begin{array}{c}\text { Type } \\
\text { of } \\
\text { biofuels }\end{array}$ & Area & Country & $\begin{array}{c}\text { First } \\
\text { reported } \\
\text { level }\end{array}$ & $\begin{array}{l}\text { Year for the } 1^{\text {st }} \\
\text { reported level }\end{array}$ & $\begin{array}{c}\text { Level for } \\
\text { year } 2017\end{array}$ \\
\hline \multirow{16}{*}{1} & \multirow{16}{*}{$\begin{array}{c}\text { Solid } \\
\text { biofuels }\end{array}$} & World & World & $26535 \mathrm{MW}$ & 2000 & $89653 \mathrm{MW}$ \\
\hline & & \multirow{3}{*}{ Africa } & South Africa & $122 \mathrm{MW}$ & 2000 & $122 \mathrm{MW}$ \\
\hline & & & Sudan & $74 \mathrm{MW}$ & 2000 & $190 \mathrm{MW}$ \\
\hline & & & Egypt & $67 \mathrm{MW}$ & 2000 & $67 \mathrm{MW}$ \\
\hline & & \multirow{3}{*}{ Asia } & China & $1100 \mathrm{MW}$ & 2000 & $10785 \mathrm{MW}$ \\
\hline & & & Japan & $964 \mathrm{MW}$ & 2000 & $2186 \mathrm{MW}$ \\
\hline & & & Indonesia & $748 \mathrm{MW}$ & 2000 & $1732 \mathrm{MW}$ \\
\hline & & \multirow[t]{3}{*}{ Europe } & Finland & $1531 \mathrm{MW}$ & 2000 & $2112 \mathrm{MW}$ \\
\hline & & & Sweden & $1527 \mathrm{MW}$ & 2000 & $4343 \mathrm{MW}$ \\
\hline & & & Germany & $422 \mathrm{MW}$ & 2000 & $2605 \mathrm{MW}$ \\
\hline & & \multirow[t]{3}{*}{ North America } & USA & $7443 \mathrm{MW}$ & 2000 & $10524 \mathrm{MW}$ \\
\hline & & & Canada & $1234 \mathrm{MW}$ & 2000 & $2355 \mathrm{MW}$ \\
\hline & & & Mexico & $321 \mathrm{MW}$ & 2000 & $778 \mathrm{MW}$ \\
\hline & & \multirow[t]{2}{*}{ South America } & Brazil & $2657 \mathrm{MW}$ & 2000 & $13088 \mathrm{MW}$ \\
\hline & & & Argentina & $545 \mathrm{MW}$ & 2000 & $640 \mathrm{MW}$ \\
\hline & & Australia & Australia & $332 \mathrm{MW}$ & 2000 & $598 \mathrm{MW}$ \\
\hline \multirow{6}{*}{2} & \multirow{6}{*}{$\begin{array}{l}\text { Liquid } \\
\text { biofuels }\end{array}$} & World & World & $5 \mathrm{MW}$ & 2001 & $2320 \mathrm{MW}$ \\
\hline & & Asia & South Korea & $356 \mathrm{MW}$ & 2014 & $359 \mathrm{MW}$ \\
\hline & & Europe & Germany & $5 \mathrm{MW}$ & 2001 & $231 \mathrm{MW}$ \\
\hline & & & Sweden & $528 \mathrm{MW}$ & 2004 & $528 \mathrm{MW}$ \\
\hline & & North America & USA & $35 \mathrm{MW}$ & 2003 & $155 \mathrm{MW}$ \\
\hline & & South America & Brazil & $4 \mathrm{MW}$ & 2013 & $4 \mathrm{MW}$ \\
\hline \multirow{12}{*}{3} & \multirow{12}{*}{ Biogas } & World & World & $2447 \mathrm{MW}$ & 2000 & $17003 \mathrm{MW}$ \\
\hline & & Africa & South Africa & $5 \mathrm{MW}$ & 2007 & $26 \mathrm{MW}$ \\
\hline & & \multirow[t]{2}{*}{ Asia } & Malaysia & $2 \mathrm{MW}$ & 2001 & $58 \mathrm{MW}$ \\
\hline & & & South Korea & $1 \mathrm{MW}$ & 2001 & $129 \mathrm{MW}$ \\
\hline & & \multirow[t]{3}{*}{ Europe } & Germany & $345 \mathrm{MW}$ & 2000 & $6157 \mathrm{MW}$ \\
\hline & & & UK & $468 \mathrm{MW}$ & 2000 & $1798 \mathrm{MW}$ \\
\hline & & & Italy & $180 \mathrm{MW}$ & 2000 & $1352 \mathrm{MW}$ \\
\hline & & \multirow[t]{3}{*}{ North America } & USA & $880 \mathrm{MW}$ & 2000 & $2394 \mathrm{MW}$ \\
\hline & & & Canada & $104 \mathrm{MW}$ & 2000 & $16 \mathrm{MW}$ \\
\hline & & & Mexico & $8 \mathrm{MW}$ & 2000 & $89 \mathrm{MW}$ \\
\hline & & South America & Brazil & $42 \mathrm{MW}$ & 2005 & $249 \mathrm{MW}$ \\
\hline & & Australia & Australia & $90 \mathrm{MW}$ & 2000 & $229 \mathrm{MW}$ \\
\hline
\end{tabular}




\subsection{Consumption}

Ethanol, as a type of bioalcohol, has the largest consumption all over the world (see Figure 2). Within Table 2, one can observe two rankings, one for ethanol consumption and one for biodiesel consumption in 2017. Ranked first for both types of biofuels in USA, which is not only the largest consumer around the world, but also the largest producer (if reporting to all three types of biofules), according to Table 1 .

Table 2. Biofuel Consumption by Country in Thousands Barrels per Day

\begin{tabular}{|c|l|c|c|l|c|}
\hline \multicolumn{1}{|c|}{ Ethanol } & \multicolumn{3}{c|}{ Biodiesel } \\
\hline Rank & \multicolumn{1}{|c|}{ Value } & Value & \multicolumn{2}{c|}{ Country } & Rank \\
\hline 1 & United States & 838 & 60 & United States & 1 \\
\hline 2 & Brazil & 359 & 49 & Germany & 2 \\
\hline 3 & China & 43 & 48 & Brazil & 3 \\
\hline 4 & Canada & 41 & 43 & France & 4 \\
\hline 5 & Germany & 27 & 27 & Spain & 5 \\
\hline 6 & United Kingdom & 17 & 16 & China & 6 \\
\hline 7 & France & 13 & 16 & Argentina & 7 \\
\hline 8 & Thailand & 9.1 & 15 & Thailand & 8 \\
\hline 9 & Italy & 8.3 & 15 & Poland & 9 \\
\hline 10 & Spain & 8 & 13 & Italy & 10 \\
\hline 11 & Sweden & 7 & 12 & Indonesia & 11 \\
\hline 12 & Colombia & 6.1 & 10 & Colombia & 12 \\
\hline 13 & India & 5.3 & 9.8 & Austria & 13 \\
\hline 14 & Netherlands & 5.2 & 8.8 & United Kingdom & 14 \\
\hline 15 & Australia & 5.1 & 6.4 & Belgium & 15 \\
\hline 16 & Finland & 5 & 6.4 & Portugal & 16 \\
\hline 17 & Poland & 5 & 6.3 & South Korea & 17 \\
\hline 18 & Philippines & 4.5 & 6 & Finland & 18 \\
\hline 19 & Denmark & 4.5 & 5.4 & Sweden & 19 \\
\hline 20 & Argentina & 5.3 & Norway & 20 \\
\hline
\end{tabular}

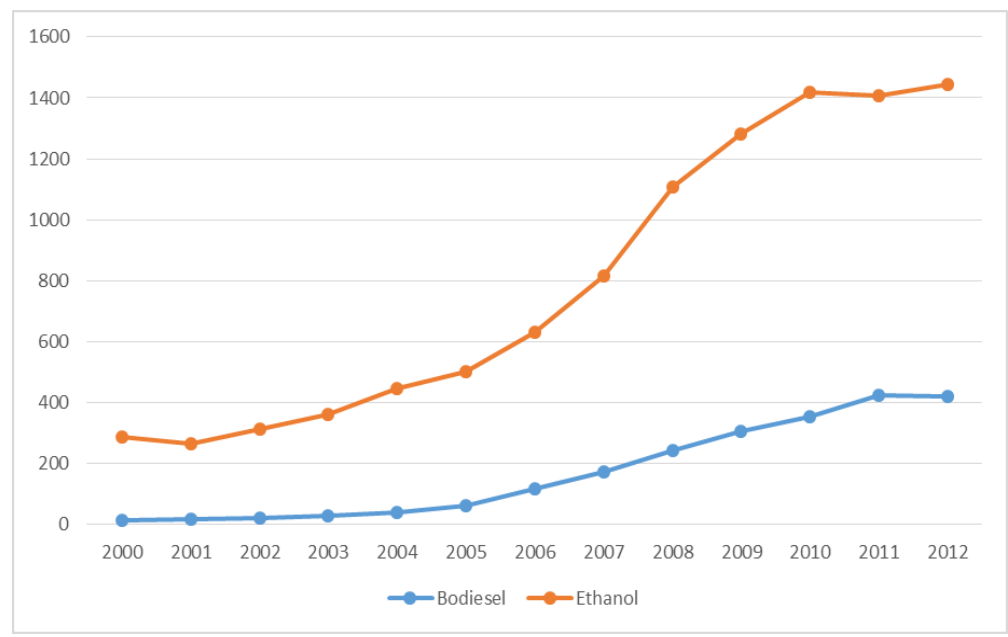

Figure 2. World Consumption of Biodiesel and Ethanol in Thousands Barrels per Day Source: Authors after Index Mundi (2018) 


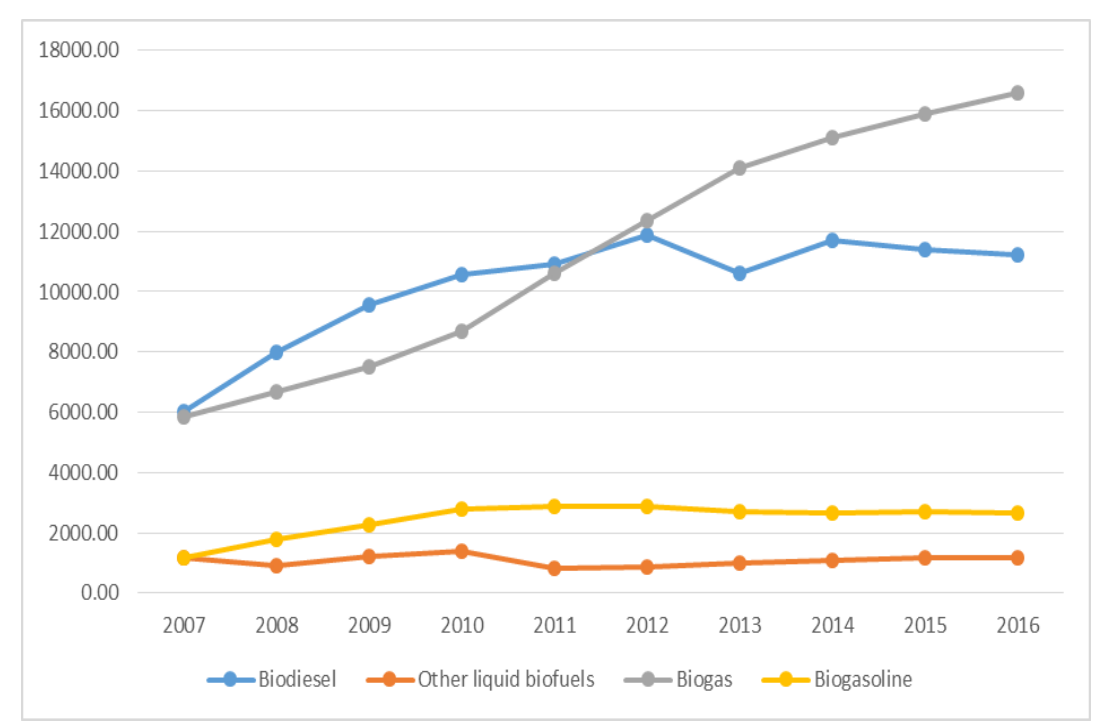

Figure 3. EU-28 Consumption of Liquid and Gaseous Biofuels in TOE Source: Authors after Eurostat (2018)

At the level of European Union with its current composition, a relevant increase may be observed in the biogas consumption, since 2007 till 2016. It is known that biogas is actually methane obtained from waste crop material through anaerobic digestion or bacteria (Biofuel.org.uk, 2010). So, as a renewable energy source, biogas became a popular also sustained by different legislative frameworks. For instance in 2009 the European Biogas Association - EBA was founded with the aim to sustain the development of biogas production and use in Europe, in order to contribute to EU's primary energy mix with almost 5\% till 2020 (European Biogas Association, 2013).

\subsection{Costs}

The wide range of technologies for renewable energy and the differences in their operation, requested a common indicator which could enable their comparison. So, the Levelised cost of electricity appeared. It is a measure depending on the specific investment cost, the operating cost of the power plant, the lifetime of the plant and financing conditions (Kost et al., 2018).

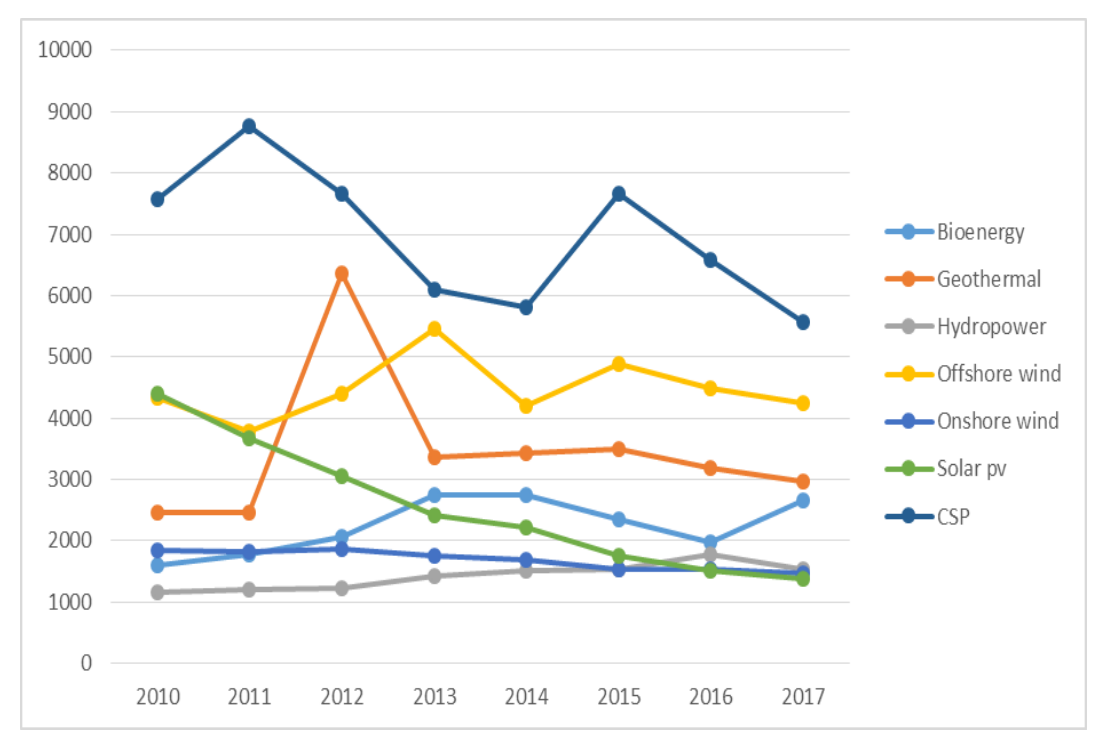

Figure 4. Total Investments Costs by Technology (in 2016 US dollars per $\mathrm{kW}$ ) - Global Source: Authors after IRENA (2018b) 


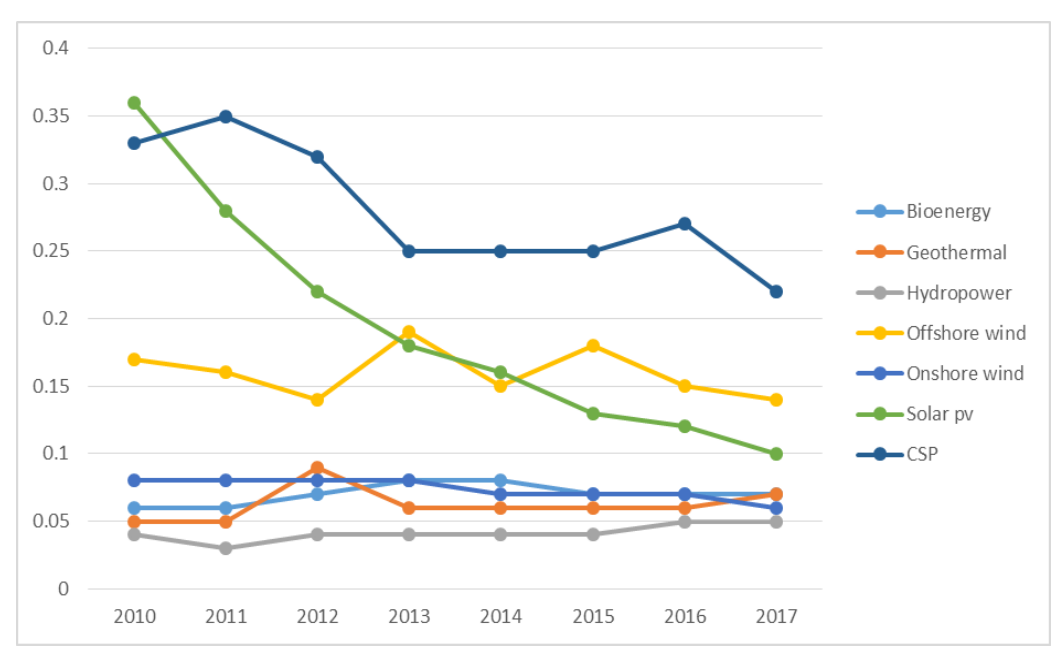

Figure 5. The Levelised Cost of Electricity (in 2016 US dollars per kW) - Global Trends Source: Authors after IRENA (2018b)

From Figure 4, one can see that the technology for producing solar energy by concentrated solar power (CSP) has the highest investment cost, followed by offshore wind and geothermal. The offshore wind technologies are also characterized by ups and downs, while the investment costs of Solar photovoltaic installations decreased over time. As shown in Figure 5, bioenergy (including biofuels) is similar to onshore wind and geothermal technologies, becoming the least expensive technologies around the world.

\subsection{Patents}

The role of patents in biofuels field innovation is a double edged sword: a measure for research output and a tool which supports the development of national policies and regulations. Patents protect valuable information for the deployment of new technologies that are to be launched on the market (IRENA, 2013).

The global overview on patents filed for biofuel technologies, at a global level is comprised in figure 6. It shows that the number of patents for both biofuels and fuels from waste increased significantly by the end of 2016, since the first reported data in 2000. According to IRENA (2018c), from 2000 to 2013, USA registered a number of 10816 patents for biofuels, followed by China with 7915 filed patents, Canada with 3166 patents, Australia with 1961 filed patents and Brazil with 1790. So, the largest consumers in the world are in the same time the first innovators within the field.

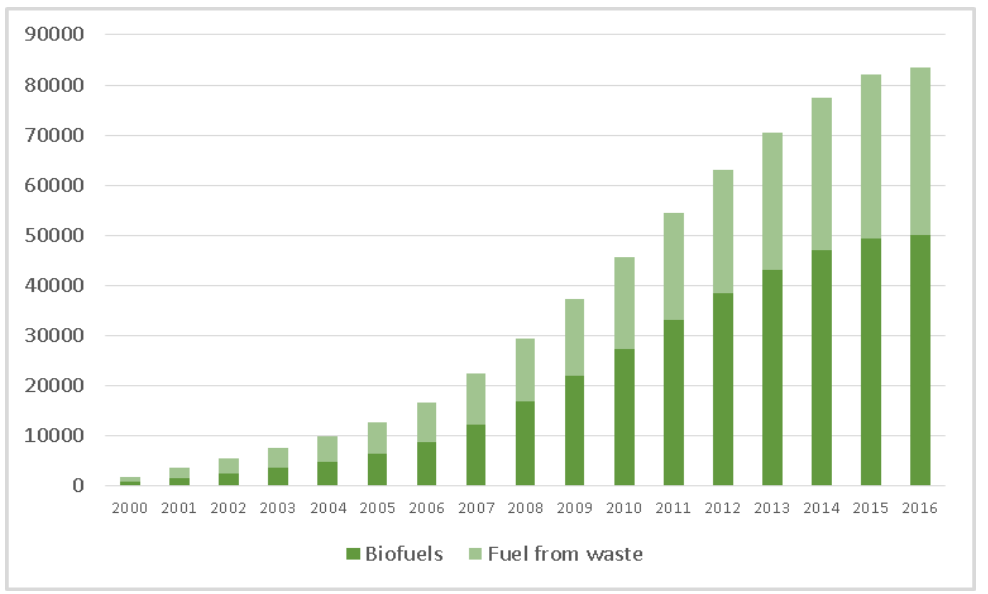

Figure 6. Patents Evolution of Biofuel Technologies - Global Trends Source: Authors from IRENA (2018c) 


\subsection{Employment}

Liquid biofuels and solid biomass technologies are the ones requesting the highest number of jobs in 2017 from a total of 10.7 million jobs around the world (IRENA, 20018d). Table 3 contains some examples of countries that not only contribute to the development of biofuels field but also offer a considerable number of jobs within this sector. The best "employer" for liquid biofuels industry is Brazil with jobs in sugarcane processing, in ethanol processing, in manufacturing and biodiesel. For gaseous and solid biofuels, China takes the lead in number of created jobs in 2017. Besides Brazil and USA, the European Union and Southeast Asian countries were among the largest employers, according to IRENA (2018d) while the biofuels employment is limited in Africa. The same agency estimates that around 2 million jobs were created within the last year, sustained mainly by the production of ethanol and biodiesel.

Table 3. Employment in the Biofuels Sector in 2017 by Technology

\begin{tabular}{|c|c|c|c|}
\hline $\begin{array}{l}\text { No } \\
\text { crt. }\end{array}$ & Technology & Country & $\begin{array}{c}\text { Number of } \\
\text { jobs in thousands }\end{array}$ \\
\hline \multirow{16}{*}{1} & \multirow{16}{*}{ Liquid biofuels } & Brazil & 795.4 \\
\hline & & USA & 299.2 \\
\hline & & Colombia & 190.8 \\
\hline & & Indonesia & 179.4 \\
\hline & & Thailand & 102.6 \\
\hline & & China & 51 \\
\hline & & India & 35.1 \\
\hline & & Poland & 34.8 \\
\hline & & France & 33.2 \\
\hline & & Germany & 23.9 \\
\hline & & Romania & 23.8 \\
\hline & & Canada & 17.7 \\
\hline & & South Africa & 6.4 \\
\hline & & Argentina & 5.5 \\
\hline & & Spain & 4.1 \\
\hline & & Japan & 3.1 \\
\hline \multirow{12}{*}{2} & \multirow{12}{*}{ Biogas } & China & 145 \\
\hline & & India & 85 \\
\hline & & Germania & 41.1 \\
\hline & & Italy & 8 \\
\hline & & USA & 7 \\
\hline & & Czech Republic & 4.3 \\
\hline & & Poland & 3.1 \\
\hline & & United Kingdom & 3 \\
\hline & & France & 1.8 \\
\hline & & Hungary & 1.5 \\
\hline & & Bulgaria & 0.8 \\
\hline & & Romania & 0.2 \\
\hline \multirow{8}{*}{3} & \multirow{8}{*}{ Solid biomass } & China & 180 \\
\hline & & USA & 79.7 \\
\hline & & India & 58 \\
\hline & & Germany & 40.6 \\
\hline & & France & 35.4 \\
\hline & & Spain & 33.4 \\
\hline & & Poland & 26.1 \\
\hline & & Finland & 25.4 \\
\hline
\end{tabular}

Source: Authors after IRENA (2018d) 


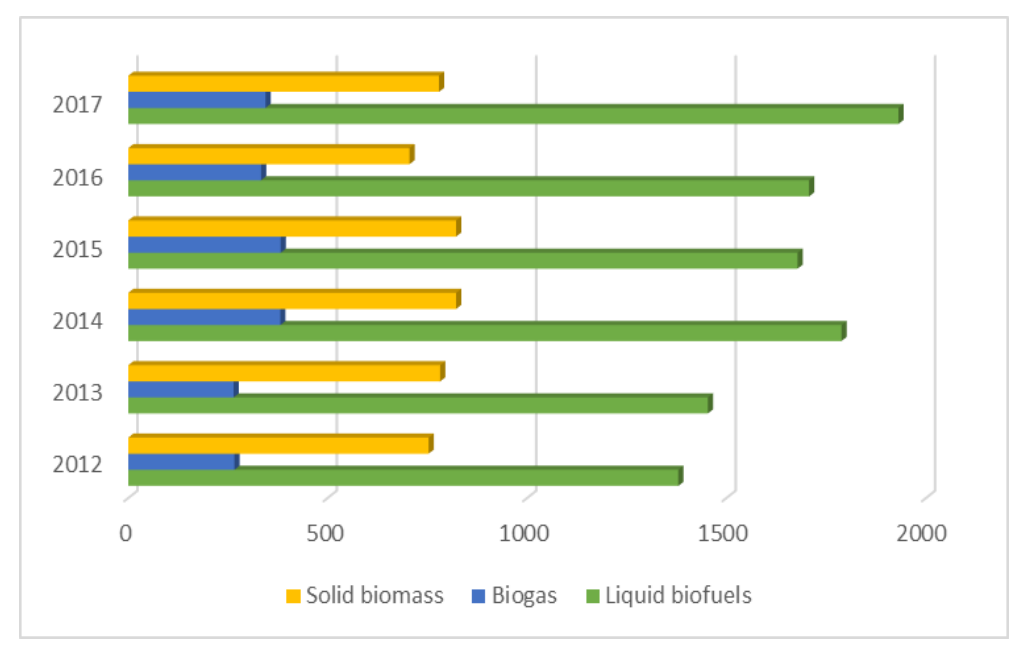

Figure 7. Employment in the Biofuels Sector between 2012-2017 Source: Authors after IRENA (2018d)

Among the three reported types of biofuels, liquid biofuels provided the highest number of jobs worldwide between 2012 and 2017, as seen in Figure 7. According to IRENA (2018d), liquid biofuels is the second type of renewable energy after solar photovoltaic providing new jobs. With a total number of 1931 thousand jobs, liquid biofuels exceeds the values registered for large hydropower - 1514 thousand jobs and wind energy - 1148 thousand jobs. The same agency reports that the global estimated employment receives half of the jobs from Latin America, while Asia provides 21\%, North America 16\% and Europe 10\%.

\subsection{Investments}

Top recipients of public investment in 2017 in bioenergy field are: Brazil with 6.3 USD billion, United Kingdom with 1.4 USD billion, followed by Finland with 0.8 USD billion, Sweden with 0.7 USD billion and France with 0.6 USD billion (IRENA, 2018e). As seen in Figure 8, 2010 was the peak year for public investments in bioenergy and afterwards the level of the public investments entered a downward trend. According to IRENA (2018e), the public sources provided only $10 \%$ of renewable energy investments worldwide in 2016.

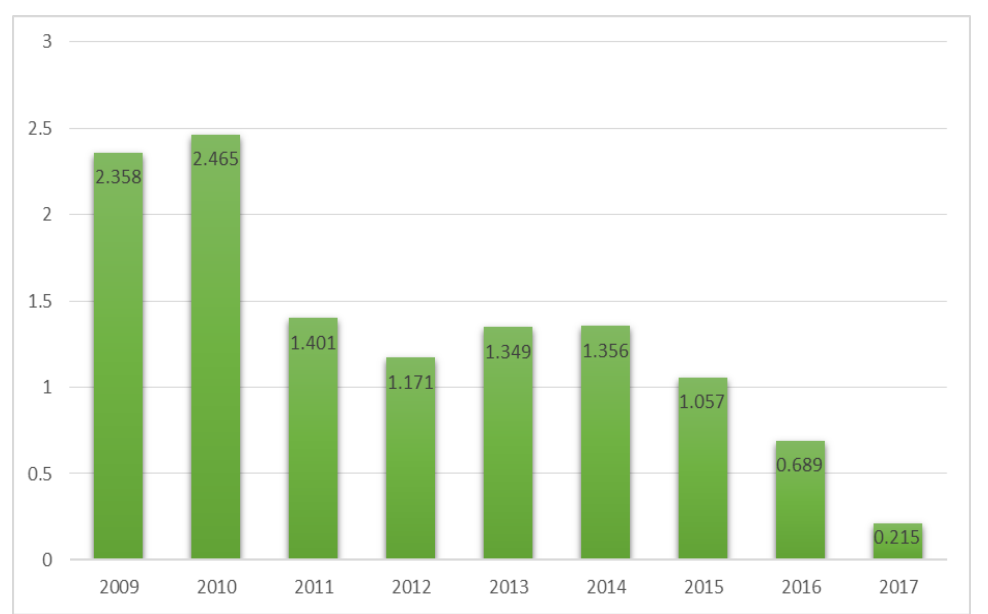

Figure 8. Public Investment Trends in Bioenergy (in billion USD) - Global Source: Authors from IRENA (2018e)

The initial high levels of public investments are understood as contributions of each country in order to fulfil pledges under the Paris Agreement. In the same time, those efforts were undertaken from climate change and other environmental considerations. 


\section{CONCLUSIONS}

As shown in this paper, bioenergy, as an industry, with solid, liquid and gaseous type of biofuels, is responsible for creating around 3 million jobs in the last year. In the same time, it is capable of providing constant flow of electricity, as it is not dependent on weather conditions as other type of renewable energy.

Integrating biofuels into our energy supply has a triple significance. Firstly, growing crops for obtaining biofuels means a greater capacity of carbon absorption. Secondly, burning biofuels is much cleaner than burning fossil fuels. Thirdly, thanks to recent growing innovations in the field, biofuels are becoming cheaper and easier to use, so the rising oil prices and their consequences may be avoided.

All in all, biofuels are a promising solution both for growing carbon emissions and energy demands. Their story could certainly exceed Diesel's and Ford's expectations about the future of greener fuels. This future means our present, a period of serious accumulation of knowledge, involvement, more collaboration than competition and efforts in the development and use of biofuels. We wish someone will ask the question once again years from now, in a present of advanced biofuels, maybe part of a well-developed fourth generation, known by a cleaner world.

\section{ACKNOWLEDGEMENTS}

This manuscript is a result of the research within the 2018-2020 Postdoctoral advanced research program from The Bucharest University of Economic Studies.

\section{REFERENCES}

Agarwal, K., Bijwe, J., \& Das, L. M. (2003). Effect of biodiesel utilization on wear of vital parts in compression ignition engine. Journal of Engineering for Gas Turbines and Power, 125(2), 604-611

Agarwal, K. (2007). Biofuels (alcohols and biodiesel) applications as fuels for internal combustion engines. Progress in Energy and Combustion Science, 33(3), 233-271. https://doi.org/10.1016/j.pecs.2006.08.003

Al-Farayedhi, A., Al-Dawood, A. M., \& Gandhidasan, P. (2004). Experimental investigation of SI engine performance using oxygenated fuel. Journal of Engineering for Gas Turbines and Power, 126(1), 178-191. https://doi.org/doi:10.1115/1.1615254

Alley, R. B. et al. (2003). Abrupt climate change. Science, 299(5615), 2005-2010. https://doi.org/10.1126/science.1081056

Biofuel.org.uk, (2010). Types of biofuels. Retrieved (http://biofuel.org.uk/types-ofbiofuels.html)

Blanchard, O. (2000). What do we know about macroeconomics that Fisher and Wicksell did not? Quarterly Journal of Economics, 115, 1375-1409

Book, J. et al. (2014). Cellulolytic Streptomyces strains associated with herbivorous insects share a phylogenetically linked capacity to degrade lignocellulose. Applied and Environmental Microbiology, 80(15), 4692-4701. https://doi.org/10.1128/AEM.01133-14

Brennan, L., \& Owende, P. (2010). Biofuels from microalgae - A review of technologies for production, processing, and extractions of biofuels and co-products. Renewable and Sustainable Energy Reviews, 14(2), 557-577. https://doi.org/10.1016/j.rser.2009.10.009 
Brunecky, R. et al. (2013). Revealing nature's cellulase diversity: the digestion mechanism of Caldicellulosiruptor bescii CelA. Science 342(6165), 1513-1516. https://doi.org/ $10.1126 /$ science. 1244273

Dahiya, A. (2005). Chapter Introduction, pages 1-4, from Part I: Bioenergy - Biomass to Biofuels: An overview, in Bioenergy, editor Dahiya A., Academic Press https://doi.org/10.1016/C2012-0-06230-8

European Biogas Association, (2013). Vision and mission. Retrived from http://europeanbiogas.eu/about-us/vision-mission/

Eurostat, (2018). Complete energy balances - annual data. Retrieved from https://ec.europa. eu/eurostat/data/database

Fargione, J. et al. (2008). Land clearing and the biofuel carbon debt. Science, 319(5867), 1235-1238. https://doi.org/10.1126/science.1152747

Food and Agriculture Organization of the United Nations, (2004). Unified Bioenergy Terminology (UBET), Rome

Hansen, C., Zhang, Q., \& Lyne, P. W. L. (2005). Ethanol - diesel fuel blends - a review. Bioresource Technology, 96(3), 277-285. https://doi.org/10.1016/j.biortech.2004.04.007

Himmel, M. E. et al. (2007). Biomass recalcitrance: engineering plants and enzymes for biofuels production. Science 315(5813), 804-807

Hoffert, M. I. et al. (2002). Advanced technology paths to global climate stability: energy for a greenhouse planet. Science 298(5595), 981-987. https://doi.org/10.1126 /science. 1072357

Index Mundi, (2018). Fuel consumption by country. Retrieved from https://www.indexmundi. com/energy/?product=ethanol\&graph=consumption\&display=rank

IRENA, (2013). Intellectual Property Rights: The Role of Patents in Renewable Energy Technology Innovation. Retrieved from http://www.irena.org/-/media/Files/IRENA /Agency/Publication/2013/Intellectual_Property_Rights.pdf

IRENA, (2018a). Installed capacity in MW - biofuels. Retrieved from http://resourceirena. irena.org/gateway/dashboard/?topic $=4 \&$ subTopic $=18$

IRENA, (2018b). Total Investments costs. Retrieved from http://resourceirena.irena.org /gateway/dashboard/?topic $=3 \&$ subTopic $=1066$

IRENA, (2018c). Patents evolution of renewable energies technologies - Bioenergy. Retrieved from http://resourceirena.irena.org/gateway/dashboard/?topic=1019\&sub Topic $=1058$

IRENA, (2018d). Employment in bioenergy. Retrieved from http://resourceirena.irena. org/gateway/dashboard/?topic $=7 \&$ subTopic $=53$

IRENA, (2018e). Investment trends. Retrieved from http://resourceirena.irena.org/gateway/ dashboard/?topic $=6 \&$ subTopic $=11$

Karl, T. R., \& Trenberth, K. E. (2003). Modern global climate change. Science, 302(5651), 1719-1723. https://doi.org/10.1126/science. 1090228

Kost, C., et al. (2018). Levelized cost of electricity renewable energy technologies. https://www.ise.fraunhofer.de/content/dam/ise/en/documents/publications/studies/EN20 18_Fraunhofer-ISE_LCOE_Renewable_Energy_Technologies.pdf

Melillio, J. M. et al. (2009). Indirect emissions from biofuels: how important? Science, 326(5958), 1397-1399. https://doi.org/10.1126/science.1180251

Naik, S. N. et al. (2010). Production of first and second generation biofuels: A comprehensive review. Renewable and Sustainable Energy Reviews, 14, 578-597 http://dx.doi.org/ 10.1016/j.rser.2009.10.003

Pacala, S., \& Socolow, R. (2004). Stabilization wedges: solving the climate problem for the next 50 years with current technologies. Science 305(5686), 968-972. https://doi.org $/ 10.1126 /$ science. 1100103 
Ragauskas, J. et al. (2006). The path forward for biofuels and biomaterials. Science 311(5760), 484. http://dx.doi.org/10.1126/science.1114736

Ravishankara, R., Daniel, J. S., Portmann, R. W. (2009). Nitrous oxide $\left(\mathrm{N}_{2} \mathrm{O}\right)$ : the dominant ozone-depleting substance emitted in the 21st century. Science 326(5949), 123-125. https://doi.org/10.1126/science.1176985

Reis, S. et al. (2012). From acid rain to climate change. Science 338(6111), 1153-1154. https://doi.org/10.1126/science.1226514

Rioboo, R., Marengo, M. \& Tropea, C. (2002). Time evolution of liquid drop impact onto solid, dry surfaces. Experiments in Fluids, 33(1), 112-124. https://doi.org/ 10.1007/s00348-002-0431-x

Sardesai, N. et al. (2013). Cytokinins secreted by agrobacterium promote transformation by repressing a plant Myb transcription factor. Science Signaling, 6 (302), ra100. https://doi.org/10.1126/scisignal.2004518

Searchinger, T. et al. (2008). Use of U.S. croplands for biofuels increases greenhouse gases through emissions from land-use change. Science, 319(5867), 1238-1240. https://doi.org/10.1126/science.1151861

Sen, S., Vaikuntanathan, V., \& Sivakumar, D. (2014). Experimental investigation of biofuel drop impact on stainless steel surface, Experimental Thermal and Fluid Science, 54, 3846. https://doi.org/10.1016/j.expthermflusci.2014.01.014

Service, R. F. (2014). Cellulosic ethanol at last? Science 345 (6201), 1111. http://dx.doi.org/10.1126/science.345.6201.1111

Şahin, Z., \& Aksu, O. N. (2015). Experimental investigation of the effects of using low ratio n-butanol/diesel fuel blends on engine performance and exhaust emissions in a turbocharged DI diesel engine. Renewable Energy, 77, 279-290. https://doi.org/ 10.1016/j.renene.2014.11.093

Wargacki, J. et al. (2012). An engineered microbial platform for direct biofuel production from brown macroalgae. Science, 335(6066), 308-313. https://doi.org/10.1126 /science. 1214547

Wijffels, R. H. \& Barbosa, M. J. (2010). An outlook on microalgal biofuels. Science 329(5993), 796-799. https://doi.org/10.1126/science.1189003

Yokoyama, H. et al. (2014). Extracellular secretion of noncatalytic plant cell wall-binding proteins by the cellulolytic thermophile Caldicellulosiruptor bescii. Journal of Bacteriology, 196(21), 3784-3792. https://doi.org/10.1128/JB.01897-14 